This is a postprint version of the following published document:

Goleza, Benjamin; Marin, Jose M. (2015). Price support by bank-affiliated mutual funds. Journal of Financial Economics, v. 115, n. 3, pp. 614-638. Available in: http://dx.doi.org/10.1016/j.jfineco.2014.10.008

(C) Elsevier

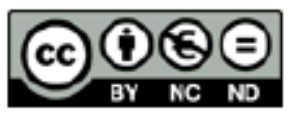

This work is licensed under a Creative Commons Attribution-NonCommercialNoDerivatives 4.0 International License. 


\title{
Price support by bank-affiliated mutual funds*
}

\author{
Benjamin Golez†, Jose M. Marin $\uparrow$
}

This version: May, 2014

\begin{abstract}
Fund managers are double agents; they serve both fund investors and owners of management firms. This conflict of interest may result in trading to support securities prices. Tests of this hypothesis in the Spanish mutual fund industry indicate that bank-affiliated mutual funds systematically increase their holdings in the controlling bank stock around seasoned equity issues, at the time of bad news about the controlling bank, before anticipated price drops, and after non-anticipated price drops. The results seem mainly driven by bank managers' incentives. Ownership of asset management companies thus matters and can distort capital allocation and asset prices.
\end{abstract}

JEL classification: G30, G23, G32, G28, G21, K22.

Keywords: Price support, conflict of interests, mutual funds, banks, secondary offerings.

†Corresponding author: University of Notre Dame, Mendoza College of Business; email: bgolez@,nd.edu; tel.:+1 574631 1458, fax: +1 5746315255.

†Universidad Carlos III de Madrid, Department of Business Economics; email: josemaria.marin@uc3m.es; tel.: +34 916249307.

* We thank Oscar Arce, Utpal Bhattacharya (the discussant), Andriy Bodnaruk, Matthew Cain, Paolo Colla, Shane Corwin, Martijn Cremers, Sevinc Cukurova, Fernando Gomez, Jens Jackwerth, Timothy Loughran, Sophie Shive; and seminar participants at the CNMV, Pompeu Fabra University, University of Notre Dame, AFA 2012 Chicago Meetings, the II World Finance Conference, and the ESSFM 2011 Gerzensee for helpful comments. We also thank Domingo Garcia (BME), Jose L. Manrique (CNMV), and Rafael Santamaria for providing data. Both authors acknowledge Financial support from the Spanish Ministry of the Economy and Competitiveness (MEC Grant ECO2012-39423). This article has been previously circulated under the title "Price Support in the Stock Market". 


\section{Introduction}

Conflicts of interest within financial institutions have recently attracted a lot of attention and are widely analyzed in the academic literature. Mehran and Stulz (2007) contend, however, that these conflicts of interest may be overrated because of regulation, self-imposed institutional controls, and the incentives of agents to take such conflicts into account in their decision making process. In this paper we identify a new conflict of interest in the asset management industry that distorts fund investment decisions and impacts asset prices despite the self-imposed controls and regulation in place.

Most individuals invest in security markets through mutual funds, pension funds, and hedge funds. These funds are managed by asset management firms, which are legal entities different from the funds they manage. Fund managers are thus "double agents" serving two principals - the fund's investors and the management firm's owners. This leads to potential conflicts of interest between these two principals. Fiduciary duty requires that the interests of the fund investors prevail, but in practice fund managers may have incentives to act on behalf of the parent firm's management and shareholders. The ownership of asset management firms may therefore matter because it can distort the allocation of capital and impact asset prices and fund performance.

This conflict of interest takes a specific form when management firms are fully owned or controlled by publicly traded companies in which the fund can invest. In these cases, the controlling company's management and shareholders could influence managers of affiliated funds to invest in the controlling company in their interests rather than the interests of fund investors. 
The extent to which controlling companies are able to influence investment decisions of affiliated funds depends on the regulation and institutional details of each country. We focus on the case of Spanish financial conglomerates or banks. Spain is a perfect candidate for our study because Spanish funds are free to hold and trade the stock of the owner (subject to some holding limits that apply to all stocks), and because Spanish banks have a prominent presence in asset management. ${ }^{1,2}$ In addition, bank affiliated management firms are located in the proximity of the controlling companies; and affiliated fund managers are often treated as employees of the controlling companies. At the same time, Spanish bank-affiliated funds tend to have loyal investors who do not chase performance (Moreno and Rubio, 2007). Finally, despite regulation on financial misconduct, the level of prosecution in Spain is relatively low. ${ }^{3}$ All this implies that Spain provides an environment in which the interest of the banks' managers and shareholders may have an impact on the investment decisions of the affiliated fund managers.

There are at least two ways in which banks could influence trading of the affiliated funds in the parent bank stock. First, affiliated funds could be used to gain friendly voting at shareholders meetings. In this case we would expect affiliated funds to overweight the parent bank (overweighting hypothesis). ${ }^{4}$ Second, affiliated funds could be used to temporarily alter the bank's share price (price support hypothesis). Because the market for corporate control in Spanish banks is historically very weak, and bank shareholders are very friendly to Board proposals, the incentives to gain voting rights through affiliated funds are small. Accordingly, we find very weak evidence for overweighting of the parent bank by affiliated funds. We find,

\footnotetext{
${ }^{1}$ U.S. funds cannot hold the stock of the controlling company, according to the Investment Company Act of 1940.

${ }^{2}$ As of 2009, funds affiliated with Spanish banks and savings and loan institutions accounted for nearly $80 \%$ of assets under management of the industry.

${ }^{3}$ In Section 5.1, we show that the level of enforcement and prosecution is much lower in Spain than in the U.S. (see also Table 2).

${ }^{4}$ Similarly, Cohen and Schmidt (2009) document for the U.S. that 401(k) trustees overweight the holdings of the sponsor firms' stock.
} 
however, strong evidence of trading by affiliated funds to support the stock price of the parent bank around important corporate events and crisis periods.

More formally, we define price support as any fund buying the shares of the parent bank in an attempt either to increase the bank's share price or to prevent it from dropping. Because trading only has a temporary effect on prices, we expect price support to take place only around events of special interest for the bank's managers or shareholders, i.e., corporate events and crisis periods.

Due to career concerns and relative performance evaluations, bank managers are especially interested in price support during times of idiosyncratic shocks in order to prevent the bank's share price from dropping and thereby avoid standing out as poor performers. ${ }^{5}$ On the other hand, bank shareholders are interested in price support during times of systemic shocks, as these periods are characterized by high marginal utility, high volatility, and low liquidity. ${ }^{6}$ Finally, both bank managers and existing shareholders are interested in price support around special corporate events such as seasoned equity offerings. ${ }^{7}$ In summary, price support is expected around specific corporate events and crisis periods (idiosyncratic and systematic shocks).

While corporate events are known in advance, crisis periods cannot always be anticipated (by management and large shareholders). In equilibrium, price support trading should therefore occur before anticipated shocks to prevent the price to fall, and after non-anticipated shocks to

\footnotetext{
${ }^{5}$ See Holmstrom $(1979,1982)$ and Diamond and Verrecchia (1982) for theoretical contributions on benefits of evaluating managers based on relative performance, and Gibbons and Murphy (1990) for supporting empirical evidence.

${ }^{6}$ For instance, see Hong et al. (2008) for theory and evidence on firms' actions (repurchases) to reduce volatility and provide liquidity.

${ }^{7}$ Firms' actions to influence the stock price around important corporate events have been documented elsewhere. For example, Ahern and Sosyura (2014) show that firms manage media coverage around mergers and acquisitions.
} 
speed up price recovery. If price support is at least partially effective, it should be observed especially when negative shocks do not result in large price drops.

Trades to support prices, however, do not come without a cost. Because the aim of these trades is to increase the bank's share price, rather than the net asset value of the fund, they may deteriorate the performance of the price-supporting funds. This can reduce the revenue from performance fees as well as fixed fees, if fund flows depend on the past performance. There is also a legal risk involved in price support as such trades may result in violations of rules against market abuse and price manipulation.

We test the price support hypothesis by analyzing how Spanish bank-affiliated funds trade in banking stocks. As noted earlier, the potential costs of price support are lower in Spain than in other countries because of low flow performance sensitivity and weak prosecution.

All the tests are based on quarterly portfolio holdings data for the period from 1995Q1 through 2009Q3. Our main sample covers the eight biggest Spanish banks and 1236 funds, of which 418 are affiliated with these banks. Consistent with our price support hypotheses, we first note that banking funds trade very differently when it comes to trading in the parent bank. While they appear to be momentum traders when trading in all the banks, and such trades are positively related to good news (analysts' recommendations and earnings forecasts), they are contrarian traders when it comes to the parent bank. They also tend to increase their holdings in the parent bank with the deterioration of public news. Finally, while trades in banking stocks overall appear informative about future returns, trades in the parent bank stock contain no superior information.

Next we show that these differences in trading patterns are largely related to price supporting trades in the parent bank. We document that affiliated funds increase their holdings in the parent bank (relative to non-affiliated funds and controlling for the other effects) at the time 
of seasoned equity issues, and that such interventions are especially strong when the bank is facing a negative outlook (as measured by sell analysts' recommendations). Furthermore, we show that affiliated funds are buying the parent bank at the arrival of bad news about the parent bank (as measured by negative revisions in analysts' earnings forecasts). Price support trading also takes place before anticipated price drops and after non-anticipated price drops. ${ }^{8}$ Because price support trading after non-anticipated price drops is much stronger in the case of idiosyncratic price drops than in the case of systematic price drops, bank managers' incentives due to peer pressure appear to be the primary driver of the documented trading patterns. We also find strong evidence of price supporting trades when the arrival of bad news is not associated with large price corrections, which implies that price supporting trades are at least partially effective. In line with the cost considerations, the results appear stronger for funds that charge exit fees and no performance fees. All the main results hold both at the fund level and the (banking) group level.

To provide additional support for our hypotheses, we reverse engineer the exercise, and focus on periods when non-affiliated banking groups are selling and the affiliated banking group is buying the parent bank. In line with our hypotheses, we find that the severity of asymmetric trading is negatively related to lagged returns, negatively related to future news about the bank, and positively related to concurrent returns. Using event analysis, our estimates indicate that the abnormal returns associated with price support in periods of asymmetric trading vary between $0.39 \%$ and $3.49 \%$ per quarter, or between 1.30 and 7.01 billion EUR in terms of the cumulative market value of banks.

\footnotetext{
${ }^{8}$ Assuming that bank managers and large shareholders have private information on the future of the bank, and thus can predict changes in earnings forecasts, we define an anticipated price drop as a price drop that coincides with negative revisions in earnings forecasts. A non-anticipated price drop is a price drop that does not coincide with negative revisions in earnings forecasts.
} 
The reported trading patterns that we attribute to price support are inconsistent with alternative explanations, such as momentum, contrarian, or timed styles of trading. Furthermore, although funds appear to follow a contrarian style when trading with the parent bank, such evidence is to a large extent diminished when controlling for crisis-related price supporting trades. Price support also goes beyond trading to reduce volatility because this strategy has no implications for trading around special corporate events, and has symmetric implications for price drops and price jumps. Yet, we find no evidence for differential trading of affiliated funds around price jumps. Finally, the documented trades are not restricted to periods of low valuations and do not predict future returns, which confirms that price supporting trades are done for reasons other than optimizing fund performance.

Overall, we identify a new conflict of interest that originates from the asset management ownership. It has a measurable impact on the fund investment decisions and prices, despite the regulation in place.

\section{Related literature}

Our paper relates to several strands of literature. First, our findings relate to other studies showing that executive compensation and career concerns incentivize managers to manipulate stock prices. Bergstresser and Philippon (2006) and Burns and Kedia (2006) show that managers attempt to manipulate prices though misreporting, earnings management, and fraudulent accounting. Ahern and Sosyura (2014) document that firms manage media coverage to influence their stock price during mergers and acquisitions. While these studies focus on the indirect ways of manipulating prices, the manipulation channel that we uncover involves actual trading of shares and therefore has a direct effect on prices. Our results also relate to the literature on share 
repurchases. Dittmar (2000) reports evidence consistent with stock repurchases taking place in low valuation periods, and Hong et al. (2008) argue that firms behave as traders of last resort using stock repurchase to provide liquidity when the stock price is far below the fundamental value. Our research uncovers an additional tool for this goal available to banks. Also, price support by affiliated funds goes beyond banks' share repurchases because it can take place around new equity issues, as we document. Furthermore, share repurchases differ in that they may be done for other reasons; to distribute capital or to target desirable leverage ratio (Dittmar, 2000).

Second, our paper is related to other studies analyzing conflicts of interest in asset management. Gaspar et. al. (2006) study incentives at the fund families' level that result in favoritism (transfer of performance from some funds to others). Our paper goes one step further and looks at incentives at the conglomerate level that result in a specific form of trading in the parent company stock. In the area of pension funds, Cohen and Schmidt (2009) document for the U.S. that 401(k) trustees overweigh the holdings of the sponsor firm's stock. Relating their findings to the Davis and Kim (2007) study of the effect of business ties between mutual funds and $401(\mathrm{k})$ plans, the documented overweighting appears to be driven by voting in favor of sponsor firms' management. Thus, it is a different phenomenon from our event-driven price support of temporary pressure on asset prices. ${ }^{9}$

Third, our paper is related to other studies investigating the role of affiliated funds in financial conglomerates. Massa and Rehman (2008) offer evidence of information "leakages" from parent banks to affiliated funds through bank lending activities. Mola and Guidolin (2009) document that affiliated analysts are likely to assign favorable ratings to stocks that are included

\footnotetext{
${ }^{9}$ As documented in Section 7.2, we find only insubstantial evidence for overweighting hypothesis in the case of Spanish bank-affiliated funds. This is consistent with a very weak market for corporate control in Spain.
} 
in the portfolios of affiliated mutual funds. Ritter and Zhang (2007) show that investment banks allocated "hot" IPOs during the 1999-2000 Internet bubble to affiliated mutual funds. While these papers document trades of potential benefit to fund investors, our paper differs in that we analyze trades of affiliated funds that can harm fund investors.

Fourth, the literature has identified other trading patterns of mutual funds, such as calendar-driven risk taking (Chevalier and Ellison, 1997), window dressing (Lakonishok et al., 1991), and stock price manipulation prior to quarterly reporting dates (Carhart et al., 2002). These trading patterns differ from price support documented here in that they are driven by fund manager's incentives (rather than controlling company's incentives) and involve all the stocks in the portfolio, not only the controlling company's stock. Our findings are also consistent with Sias et al. (2006) that institutional trades have a price impact.

Fifth, price support activities have been analyzed in the context of the IPO to explain part of the IPO underpricing (Ruud, 1993; Ellis et al., 2000; Schultz and Zaman, 1994; Lewellen, 2006). Unlike the price support documented here, however, price support in the IPO business does not result from a double agency problem (but rather from the underwriter's interest in improving its reputation or compensating IPO participants for providing relevant information in the pre-IPO stage), is entirely legal, and is confined to a single brief period in the security's history.

Finally, our analysis contributes to the literature on the role of financial institutions and the legal system in the efficient allocation of capital (La Porta et al., 2000; Wurgler, 2000; Bhattacharya and Daouk, 2002; Durnev and Kim, 2005).

\section{Hypotheses}


We define price support as any fund buying the shares of the (parent) bank in an attempt to either temporarily increase the bank's share price or prevent it from dropping. Such trading is a form of subsidy that could be advantageous to bank managers and bank shareholders, but not necessarily to fund investors. Because trading only has a temporary effect on prices, we anticipate price support to take place only around special events.

To develop testable hypotheses, we next analyze incentives for price support and the associated costs.

\subsection{Incentives for price support}

Price support can be beneficial to bank managers and bank shareholders (or the bank itself). Bank managers might resort to price support because of career concerns or peer competition, and because compensation is typically linked to share prices. The existing literature shows that stock-based executive compensation incentivizes managers to manipulate stock prices through misreporting, earnings management, and fraudulent accounting [see Peng and Roell (2008) and Benmelech et al. (2010) for recent theoretical contributions and Bergstresser and Philippon (2006) and Burns and Kedia (2006) among others for supporting empirical evidence]. We anticipate that the same incentive structure would also lead managers to manipulate prices by influencing affiliated funds. According to the agency theory, there are benefits associated with evaluating agents on the basis of their relative performances (Holmstrom, 1979; 1982; Diamond and Verrecchia, 1982). Gibbons and Murphy (1990) provide empirical evidence by documenting that both market-wide shocks and industry shocks are filtered from stock price performance when deciding on the CEO dismissal. This suggests that managers would be especially interested 
in price support in times of idiosyncratic shocks in order to prevent the price from dropping and thereby avoid standing out as poor performers. ${ }^{10}$

Bank shareholders, like any other investors, maximize their utility. They are interested in high prices, high liquidity, and low volatility. Hong et al. (2008) reports evidence consistent with firms using share repurchases to provide liquidity and stabilize the stock price in low valuation periods. These trades tend to reduce short-term volatility. In the same vein, bank shareholders are interested in price support (using affiliated funds) in low valuation periods. ${ }^{11}$ Since marginal utility is especially high during market crises, shareholders' incentives for price support are the biggest during bank shocks that coincide with negative market corrections (systematic shocks).

Bank managers and bank shareholders also have an interest in price support at the time of important corporate events. For example, Ahern and Sosyura (2014) show that firms manage media coverage to influence their stock price around mergers and acquisitions. Similarly, we may expect affiliated funds trading to support the price of the parent bank around important corporate events, including seasoned equity issues. ${ }^{12}$ Companies typically time the market by offering new shares when the market is optimistic about the prospects of the company (Loughran and Ritter 1995, 1997; Baker and Wurgler, 2002). During such times, incentives for price

\footnotetext{
${ }^{10}$ For remuneration reasons price support can also take place around evaluation periods (e.g. executive option expiration dates). Consistent with backdating reported by Heron and Lie (2007), managers would be interested in depressing the price at the time when options are granted and in inflating the price at the options expiration dates. Unfortunately, Spanish data on remuneration of top executives disclosed in the Governance Reports submitted to the CNMV starts only in 2004 and is insufficient to test this hypothesis.

${ }^{11}$ The literature on share repurchases uses the market-to-book ratio as the proxy for high/low valuations. In this paper we directly look at stock returns to identify intervention periods because our focus is on temporary shocks rather than prolonged periods of under/overvaluation.

${ }^{12}$ Likewise, we may expect price support around acquisitions and mergers in which the bank uses shares as the means of payment. To test this hypothesis, however, we would need the exact dates when fixed or flexible exchange ratios were determined (Ahern and Sosyura, 2014). Because such data does not exist for Spain, we do not pursue this test. For the same reason, we also exclude from our analysis all new equity issues motivated by bank acquisitions. Price support may also be beneficial in the case of hostile takeovers to deter a hostile takeover where the bank is the target. However, there was not a single attempt (successful or unsuccessful) to take over a Spanish bank during our sample period 1996-2009, and we therefore do not pursue this test either.
} 
support are present, but not as strong as in times of negative outlook regarding the issuing company's stock market performance. Thus, we expect price support to be especially strong in the subset of new equity issues that coincide with the selling pressure upon the banks' shares. ${ }^{13}$

\subsection{Costs of price support}

The primary goal of price support trading is to increase the bank's share price rather than to maximize the net asset value of the fund. Such trades may therefore deteriorate funds' performance and reduce the revenue from performance fees. Insofar as net-flows depend on funds' performance, price-supporting trades may also lead to fund outflows, and thereby reduce the revenue from fixed fees. This could hamper affiliated management firms' profitability, and possibly reduce the value of the whole bank.

There is also a legal risk involved in price support as fund managers have a fiduciary duty, and the trading may result in violation of rules against market abuse and price manipulation. The expected legal cost is increasing due to monitoring and prosecution intensity by regulators.

\subsection{Price support hypotheses}

\footnotetext{
${ }^{13}$ Price support can also be beneficial to banks in general if market prices are used to infer the solvency of banks and their borrowing costs in the interbank market (Gropp et al., 2006). To the extent that a bank's share price may convey a signal about the quality of affiliated management companies, price support trading could also be beneficial to the affiliated-mutual funds. Sialm and Tham (2014) document that the stock performance of publicly traded management firms conveys information about the financial health of the management company, and thus affects fund flows. It may therefore be in the interest of affiliated funds to support the parent bank stock to avoid negative inferences on the quality of management. However, if a decrease in the bank's share price conveys a bad signal, the deterioration in fund performance arising from price support may be associated with an even bigger price decrease. Thus, unless we consider a situation with strong non-linearities in marketing, such strategy would not be viable from the funds' perspective.
} 
Based on the above considerations of incentives for price support and the associated costs, we now develop testable hypotheses. The cost considerations of price supporting trading put a restriction on our sample choice as we should expect price support activities to be present only in countries where fund flows are not very sensitive to performance, and in countries with lenient regulation or weak prosecution. Also, we should not observe price support trading in countries where the stock of the parent bank is not allowed in the portfolio of affiliated funds. As we explain below, we conduct the analysis in the case of Spain, where all the above conditions are satisfied.

Based on considerations of incentives for price support, we may observe price support trading around important corporate events (new equity issues) and around crisis periods (large price drops and/or arrival of bad news about the bank). The exact timing of price support trading, however, depends on whether or not such events are anticipated. In the case of anticipated events, price support trading should precede or coincide with the event itself. In the case of nonanticipated events, trading should take place right after the event.

First, corporate events are known in advance and hence price support activities can be timed exactly.

Hypothesis (1): Corporate events. Price support trading takes place at the time of banks' seasoned equity offerings, and is especially strong when new equity issues coincide with the selling pressure upon the banks' shares.

Next, we develop the hypotheses related to trading around crisis periods. The main goal of price support trading around such periods is to prevent the price from dropping. Price support trading should therefore coincide with the arrival of bad news about the parent bank. Insofar as 
funds are successful in preventing price corrections, price support trading would be especially strong when the arrival of bad news is not associated with price drops.

Hypothesis (2): Price impact. Price support trading coincides with the arrival of bad news about the parent bank and is more pronounced when the arrival of bad news does not coincide with a drop in the price of the parent bank.

Finally, price support trading may not always be fully effective. We may occasionally observe price drops despite the price support trading. Some price corrections can be anticipated (by insiders) and we should therefore observe price support trading before such price drops. Price corrections, however, can also occur because of unanticipated external factors. In the latter case, affiliated funds are taken by surprise and step in to support the price of the parent bank after a large price correction to speed up price recovery.

Non-anticipated price corrections can be further divided into non-anticipated systematic price drops and non-anticipated idiosyncratic price drops. As discussed above, such division is important to pin down the motives for price support trading. According to the marginal utility argument, shareholders are more concerned about systematic drops. Managers, due to peer competition, however, are more interested in price support around idiosyncratic price drops. These considerations lead us to our third hypothesis.

Hypothesis (3): Price drops and incentives for price support. Price support trading takes place before anticipated price drops and after non-anticipated price drops. If price support trading is largely driven by managers' incentives, it should be stronger in the case of non-anticipated idiosyncratic price drops. If price support trading is largely driven by shareholders' incentives, it should be stronger in the case of non-anticipated systematic price drops. 
Price support buying around crisis periods is aimed at reducing the downside potential of the stock price. Funds, however, cannot hold unrestricted amounts of the parent bank, and therefore occasionally need to download the holdings that they accumulate in the crisis periods. Thus, the combination of buying in the crisis periods (especially after non-anticipated price drops) combined with the possible downloading of their accumulated holdings in non-crisis periods may make affiliated funds look like contrarians when trading with the shares of the parent bank.

\section{Empirical procedure}

We test the above hypotheses by comparing trading of affiliated funds to trading of nonaffiliated funds while controlling for the main variables known to influence fund trading behavior. We estimate the following pooled regression model: ${ }^{14}$

$$
\begin{aligned}
\Delta H_{f, i, t}= & \beta_{0}+\beta_{1} \text { BANK }_{f, i, t}+\beta_{2} \operatorname{AFFIL~}_{f, i, t}+\beta_{3} \operatorname{EVENT}_{i, t}+\beta_{4} \operatorname{EVENT}_{i, t} \times B A N K_{f, i, t}+ \\
& \beta_{5} \operatorname{EVENT}_{i, t} \times \operatorname{AFFIL}_{f, i, t}+\gamma \operatorname{CONTROLS}_{f, i, t}+\varepsilon_{f, i, t},
\end{aligned}
$$

where $\Delta H_{f, i, t}$ is the change in the holdings of fund $f$ in the stock of bank $i$ at time $t . B A N K_{f, i, t}$ is a dummy equal to 1 if fund $f$ belongs to any of the banks $i$ in our sample at time $t$. $A F F I L_{f, i, t}$ is a dummy equal to 1 if fund $f$ is affiliated with bank $i$ at time $t$. EVENT $i, t$ is a dummy equal to 1 if an event (special corporate event or crisis) takes place in bank $i$ at time $t$. $\operatorname{CONTROLS~}_{f, i, t}$ is a vector of standard control variables. The estimated parameter on the interaction term $E V E N T_{i, t} * B A N K_{f, i, t}$ captures how funds affiliated to banks trade with all the banking stocks. The estimated parameter on the interaction term $E V E N T_{i, t} * A F F I L_{f, i, t}$ captures the differential trading of affiliated funds with the parent bank.

\footnotetext{
${ }^{14}$ The dependent variable and events are defined in Sections 5.4 and 5.5, respectively. Control variables are defined in Appendix A.
} 
All the tests are based on quarterly mutual funds holdings data. In the case of anticipated events, we test for trading in the quarter before the event or during the event. In the case of nonanticipated events, we test for trading in the quarter after the event. We focus our attention mainly on testing hypotheses at the fund level, but report as well all the tests at the level of controlling companies (group level).

\section{The institutional settings, data, and variable definitions}

\subsection{The institutional settings}

We place our study in the context of the Spanish mutual fund industry. This section highlights some key features of this industry, the market where banks trade, and the regulatory framework. Table 1 collects the summary statistics.

The Spanish mutual fund industry is comparable in size to other European countries, but much smaller than in the U.S. As of 2009, total assets under management amounted to 279 billion (in dollar terms), which represented 18\% of the Spanish GDP. This percentage is slightly above the Italian figure (15\%) but well below the U.K. (40\%), French (54\%), and, especially, the U.S. (80\%) figures. Average AUM/GDP ratio for 1997-2009 is approximately the same for the Spanish, the Italian, and the U.K. markets (25\%).

Spanish funds are relatively more expensive and charge higher exit fees than funds elsewhere. Cremers et al. (2013) find a total expense ratio (TER) of $2.01 \%$ for Spain, which is much higher than the $0.99 \%$ for the 20 -country average. Ferreira et al. (2012) report exit fees of $0.92 \%$ for Spain, while the average for a sample of 28 countries is $0.64 \%$. Gil-Bazo and Martinez (2004) document that Spanish mutual funds charge the highest fees among 10 European countries. 
Spanish funds also seem to be relatively poor performers. Ferreira et al. (2012) find average Jensen's alphas for Spanish equity funds of $-1.68 \%$, while the sample average for 28 countries is $-0.47 \%$. Ferreira et al. (2012) identify Spain as the worst performer in terms of Jensen's alphas, and the second to last in terms of 4-factor alphas.

There are several stylized facts regarding banks' involvement in asset management in Spain. First, financial intermediaries have a heavy presence in delegated portfolio management in Spain. In 2009, funds affiliated with Spanish banks accounted for nearly half of the assets under management of the Spanish mutual fund industry. If we add the funds affiliated with Spanish savings and loan institutions, the share of total assets under management increases to nearly $80 \%$. The comparable presence in the United States is below $40 \% .{ }^{15}$ Second, there is also ample evidence that Spanish banks tend to have very loyal clients who most often invest in their bank-affiliated mutual funds without shopping for quality, which results in a low (even negative) relation between net flows and risk-adjusted performance (Moreno and Rubio, 2007). Third, Spanish bank-affiliated mutual funds seldom use performance fees and charge higher exit fees than non-affiliated funds. ${ }^{16}$

[Insert Table 1: Comparative analysis of the Spanish mutual fund industry]

Another feature of the Spanish asset management industry is limited career opportunities for fund managers. Star managers are virtually non-existent in Spain (Cinco Dias, 2003). This is because of the dominance of banks as opposed to markets. Unlike in the U.S. or the U.K., where fund investors rely on independent advisors who base their recommendations on track records, in

\footnotetext{
${ }^{15}$ In the United States, Frye (2001) reports that $14 \%$ of all mutual funds were managed by banks in 1999. If one adds insurance institutions, Massa and Rehman (2008) find that the percentage increases to $40 \%$.

${ }^{16}$ For instance, in our sample of 769 funds in 2009Q3, only $10.3 \%$ of funds charge performance fees. This percentage is approximately the same for bank-affiliated funds $(10.0 \%)$ and non-affiliated funds $(10.4 \%)$. Bankaffiliated funds, however, charge exit fees more often than non-affiliated funds (43.9\% versus $24.7 \%)$. Exit fees are also slightly higher on average for bank-affiliated funds than for non-affiliated funds ( $1.32 \%$ compared to $1.14 \%)$.
} 
Spain, fund investors mainly rely on the advice of bank branches to make their investment decisions. Thus, the incentives for fund managers to build a track record are weak, especially for bank-affiliated funds. This is consistent with the relatively low salary for Spanish fund managers in general and the view of managers of affiliated funds as bank employees rather than entrepreneurs seeking independent careers. ${ }^{17}$

The banks in our study trade on the Madrid Stock Exchange (MSE), which is the 14th largest stock market in the world, according to the 2011 World Federation of Exchanges report. An important feature of the Spanish market in general and the banking sector in particular is the weak market for corporate control. It is generally accepted that the specific regulation of banks reduces the effectiveness of external control mechanims (Prowse, 1997; Crespi et al., 2004). This is more than evident in the Spanish case, in which not a single attempt of a hostile domestic takeover occured during the period of our analysis, according to Thomson One Investment Banking database. The distinctive characteristic of the Spanish case, however, is the dominance of large shareholders. Stein et al. (2012) document that $37.5 \%$ of the voting rights of the average Spanish bank are held by a single shareholder. The only exceptions are the two largest banks Banco Santander and BBVA - whose ownership is dispersed. However, these are characterized by very accomodating shareholders who never reject board proposals in the General Meetings. ${ }^{18}$

Regulation is another important feature of the Spanish market. While shares of the parent bank are treated in Spain like any other type of security, in the U.S. such stocks have not been allowed since the Investment Company Act of 1940. Thus, while Spanish affiliated funds are

\footnotetext{
${ }^{17}$ Funds People (2012) estimates that the average base salary of a Spanish senior manager is 75,000 euros. According to Cerulli Associates, $40 \%$ of the managers of the top management firms worldwide earned a base salary of 225,000 euros in 2012.

${ }^{18}$ According to the CNMV and the information on banks' webpages, $100 \%$ of Board proposals in the General Meetings of Santander and BBVA in the period from 2004 onward were approved by shareholders (by at least $75 \%$ of the votes).
} 
free to hold and trade the stock of the parent bank (subject to some holding limits that apply to all stocks), affiliated mutual funds in the U.S. cannot even hold such stocks. ${ }^{19,20}$

Finally, observed levels of prosecutions are very low in Spain. Table 2 compares the U.S. and Spanish securities commissions (CNMV) in terms of track records on crime investigation and prosecution from 2004 to 2009. U.S. data (Panel A) comes from the SEC Performance and Accounting Report and SEC Statistics; Spanish data (Panel B) is from CNMV Annual Reports. ${ }^{21}$ Large differences are evident in the number of investigations opened, investigations closed, and enforcement. While many of these differences could be explained by the relative size of the two countries' financial sectors, the differences in enforcement related to asset management clearly suggest that crime investigation and prosecution in Spain is much weaker than in the U. S.

[Insert Table 2: Law enforcement by U.S. versus Spanish regulators]

\subsection{Data sources}

We merge data from two main sources: the Spanish SEC (CNMV) and Datastream. From CNMV we obtain funds quarterly portfolio holdings and funds characteristics for all mutual funds registered in Spain in the period from 1995Q1 through 2009Q3. ${ }^{22}$ The data provide all the

\footnotetext{
${ }^{19}$ See Section 12 of the Investment Company Act of 1940. Several exemptions were introduced recently, such as those allowing temporary holdings in the case of mergers and acquisitions, but the general restriction is still binding. ${ }^{20}$ The Spanish law dictates that asset management firms must establish internal control mechanisms to supervise all transactions with securities issued by affiliated companies (companies in the same group as the management firm).

${ }^{21}$ The figures for civil cases are not entirely comparable. The Spanish SEC does not have the authority to initiate civil or criminal proceedings, so all cases are of an administrative nature. The CNMV merely forwards to the General Attorney cases that could be taken to trial. The U.S. figures reflect actual civil proceedings.

${ }^{22}$ The data include public databases FONDCART and FONDOS, and direct searches of the CNMV registry to obtain fund merger dates. First mergers between funds in Spain took place in 2001. Starting in 2008Q4, 10 funds in our sample created subfunds. For the purpose of our analysis, we manually aggregate subfunds into a single fund.
} 
standard funds characteristics and also identify the asset manager (fund family) for each fund and the controlling group (ownership) of each of these fund managers.

From Datastream we obtain stock price, market capitalization, and market-to-book data for banks and the Madrid SE General Index for the period from 1990 through 2009. We merge fund data (CNMV dataset) and bank stock data (Datastream) using a unique identifier for each security in the portfolio, the ISIN code. ${ }^{23}$

From IBES we obtain analysts' annual earnings forecasts and recommendations. The information on mergers and acquisitions is from SDC data and bank fillings with the CNMV. We check for takeover activity in Thomson One Investment Banking database.

\subsection{Controlling banks and affiliated funds}

For a bank to be included in the treatment group, it must satisfy three criteria: (i) the bank has to control at least one asset management firm, (ii) the bank is incorporated in Spain and be traded on the Madrid Stock Exchange for at least two consecutive years during our sample period, and (iii) the bank is not controlled by another corporation. If the bank is controlled by another corporation, the CNMV data assign the asset management company to its controlling shareholder. ${ }^{24}$

We manually match the controlling groups of asset management firms from the CNMV data with the Datastream data on active and dead banks listed on the Madrid SIBE. This process results in a total of 12 banking groups. The sample of banks includes two of the largest banks in the world, Banco Santander and Banco Bilbao Vizcaya Argentaria (BBVA), as well as medium-

\footnotetext{
${ }^{23}$ Because ISIN codes change over time (with stock splits) and Datastream provides only the current codes, we obtain from the Madrid Stock Exchange the ISIN history for all the banks in our sample.

${ }^{24}$ For example, the asset management firm of Banesto is assigned to Banco Santander Central Hispano, which owns more than $90 \%$ of Banesto.
} 
and small-sized banks. Some small banks have very low free float and are very illiquid. Their stock rarely enters the portfolios of institutional investors. We therefore additionally impose a liquidity criterion that the bank has to have an average annualized standardized trading volume (annualized ratio of volume to market capitalization) above 20\%. Table 3 reports this measure for all the banks. Imposition of the liquidity criterion excludes the four banks at the end of the table. ${ }^{25}$ The final sample consists of eight banks: Banco Bilbao Vizcaya Argentaria (BBVA), Argentaria (dead), Banco Santander, Banco Central Hispano (dead), Bankinter, Banco Popular, Banco Pastor, and Banco Sabadell. Henceforth we refer to funds managed by asset management firms controlled by these eight banks as "affiliated funds" to distinguish them from the rest of the funds, "non-affiliated funds.",

\section{[Insert Table 3: Banks]}

We eliminate all funds that did not hold shares of any of the 8 banks during our sample period. We also eliminate 29 funds that have incomplete time series and funds with AUM below 1 million euros, as is standard in the literature. After these filters, the initial universe of 4254 unique funds is reduced to 1236 funds, of which 418 are affiliated funds. ${ }^{26}$

Table 3 presents the distribution of affiliated funds and fund families. Approximately one-third of the affiliated funds (149 funds) belong to Banco Santander. This compares to 85 funds for BBVA and 76 funds for Banco Sabadell. The other banks have between 8 and 34 funds. The picture is similar when we look at the number of fund families for each bank.

\footnotetext{
${ }^{25}$ The smallest banks also have incomplete or poor IBES analysts' coverage, which we need to differentiate between anticipated and non-anticipated price drops. In Online Appendix we show that our main results are robust to inclusion of Banco Zaragozano and Banco Guipuzcoano, for which complete, although poor, analysts' coverage is available.

${ }^{26}$ To control for incubated funds, it is standard in the literature to require funds to be older than one year. We impose this filter indirectly by requiring a non-missing value of fund's lagged annual return, which we use as a control variable.
} 


\subsection{Definition of variables}

Our main dependent variable is a measure of fund trading activity. For each fund $f$ we have the holdings of each banking stock $i$ at the end of quarter $t, A_{f, i, t}$, in euro terms. To alleviate the effect of price changes, we normalize holdings by the market capitalization of the security and define $H_{f, i, t}$ as the percentage of bank $i$ held by fund $f$ at the end of quarter $t::^{27}$

$$
H_{f, i, t}=\frac{A_{f, i, t}}{M C_{i, t}},
$$

where $M C_{i, t}$ is market capitalization of bank $i$ in quarter $t .^{28}$ Our measure of trading is then the change in standardized holdings:

$$
\Delta H_{f, i, t}=H_{f, i, t}-H_{f, i, t-1} .
$$

At the group level, trading activity $\Delta H_{G, i, t}$ is defined as the sum of changes in portfolio holdings $\Delta H_{f, i, t}$ for all the funds that belong to group $G$ at time $t$.

Control variables are motivated by the recent literature and include fund net flows $N E T F L O W_{f, t}$, fund assets under management $A U M_{f, t}$, fund family assets under management $A U M(F F)_{F, t}$, fund lagged annual returns $L A G R E T_{f, t}$, fund fees $F E E S_{f, t}$, fund style of investment $S T Y L E_{f, t}$ (due to data availability restrictions $S T Y L E_{f, t}$ is included only in the robustness analysis), and time dummies. To control for public information on banks' valuation, we also include analysts' recommendations, $R E C_{i, t .}{ }^{29}$ When conducting tests at the group level, we make appropriate changes in the fund related control variables. Exact definition of control variables at the fund and group level is provided in Appendix A.

\footnotetext{
${ }^{27}$ We assign a holding of zero $\left(H_{f, i, t}=0\right)$ to funds that do not hold bank $i$ in quarter $t$. In Online Appendix, we show that results are much stronger if we exclude observations with zero holdings.

${ }^{28} \mathrm{We}$ also replicate the analysis in terms of portfolio holdings, that is, in terms of the ratio of quarterly holdings to funds' assets under management. The results survive and are reported in Online Appendix.

${ }^{29}$ The results are unaffected if we use market-to-book ratio instead of analysts' recommendations. In some parts of the paper we also use analysts' recommendations as a proxy for buying/selling pressure upon the stock.
} 


\subsection{Definition of events}

We use official records to determine the timing of new equity issues. Details are provided in Appendix B. To determine crisis periods, we combine price data and analysts' earnings forecasts. We use returns data to determine large price drops. ${ }^{30}$ Analysts' earnings forecasts are used to time arrival of bad news. ${ }^{31}$

Under the assumption that bank managers and large shareholders have private information on the future of their parent bank, they then can anticipate the arrival of bad news; that is we postulate that they can predict negative revisions in earnings forecasts. We define changes in analysts' earnings forecasts as:

$$
\Delta A E F_{i, t}=\frac{A E F_{i, t}-A E F_{i, t-1}}{A E F_{i, t-1}},
$$

where $\triangle A E F_{i, t}$ is the median estimate of the first fiscal year annual earnings forecast for bank $i$ in quarter $t$. If the first year forecasts are not available (at both quarter $t$ and $t-1$ ), we rely on the second year annual earnings forecasts. The variable Bad News for bank $i$ in quarter $t$ is then defined as a binary variable:

$$
\operatorname{Bad} \operatorname{News}(a)_{i, t}=\left\{\begin{array}{lr}
1 & \text { if } \Delta A E F_{i, t}<a \\
0 & \text { otherwise. }
\end{array}\right.
$$

\footnotetext{
${ }^{30}$ We rely on returns data rather than measures for misvaluation (such as market-to-book ratio) because our focus is on temporary shocks rather than prolonged periods of under/overvaluation. In Online Appendix, we show that all our results survive if we use changes in the market-to-book ratio rather than returns.

31 The evidence suggests that analysts' earnings forecasts convey new information and, consequently, changes in analysts' forecasts have a price impact (Givoly and Lakonishok, 1979; 1980; Imhoff and Lobo, 1984; Gleason and Lee, 2003). This makes downward revisions in analysts' forecasts a good proxy for bad news and for the phenomenon we are analyzing (bank managers' interest in avoiding or correcting price drops). Alternatively, we could use accounting earnings. Accounting data, however, depend on an arbitrary use of valuation methods and are often manipulated. Moreover, Elton et al. (1981) show that foreknowledge of analysts' revisions is more relevant for securities prices than foreknowledge of the reported earnings themselves.
} 
In the main analysis we set $a$ to -0.050 . In Online Appendix we report results also for $a$ equal to -0.025 and -0.075 .

We next define large price drops using the time series of bank return. Following Marin and Olivier (2008), for each bank $i$, we first compute the monthly average return $r_{i, t, m}$ and the monthly standard deviation of returns $\sigma_{i, t, m}$ at the end of each quarter $t$ over a rolling window of the past 60 months of data. ${ }^{32}$ Then we transform the monthly average and standard deviation of returns to quarterly frequency. Finally, for any bank $i$, a large price drop is realized in any quarter $t$ in which bank $i$ return in quarter $t, r_{i, t}$ satisfies

$$
\operatorname{Bank} \operatorname{Drop}(b)_{i, t}=\left\{\begin{array}{lr}
1 & \text { if } r_{i, t}-\bar{r}_{i, t-1}<b \sigma_{i, t-1} \\
0 & \text { otherwise }
\end{array}\right.
$$

where $\bar{r}_{i, t-1}$ is the bank's average historical return described above and $\sigma_{i, t-1}$ is the bank's historical volatility. The size of the drop is determined by a constant $b$. In the main body of our analysis we set $b$ equal to -0.50 . In Online Appendix we report results also for $b$ equal to -0.25 and -0.75 .

To distinguish between systematic and idiosyncratic price drops, we first define a large price drop for the banking index. We define the banking index as the equally-weighted average return of all the banks in our sample. ${ }^{33}$ A binary variable Systematic Drop is defined as in the Bank Drop except that we replace banks' returns with the banking index:

$$
\text { Systematic Drop }(b)_{t}=\left\{\begin{array}{lr}
1 & \text { if } r_{M, t}-\bar{r}_{M, t-1}<b \sigma_{M, t-1} \\
0 & \text { otherwise }
\end{array}\right.
$$

where $M$ stands for the banking index.

\footnotetext{
${ }^{32}$ If the stock has not been publicly traded for 5 years, we require at least 2 years of data.

${ }^{33}$ In Online Appendix, we show that our results are not much affected if we substitute our banking index with the market index (Madrid general SE index).
} 
We then define the variable Systematic Bank Drop as a Bank Drop that coincides with the Systematic Drop:

$$
\text { Systematic Bank Drop } p_{i, t}=\left\{\begin{array}{cc}
1 & \text { if Bank } \text { Drop }_{i, t}=1 \text { and Systematic Drop } \\
0 & =1 \\
0 & \text { otherwise. }
\end{array}\right.
$$

Similarly, we define the variable Idiosyncratic Bank Drop as a Bank Drop that does not coincide with the Systematic Drop:

$$
\text { Idiosyncratic Bank Drop }_{i, t}= \begin{cases}1 \text { if Bank } \text { Drop }_{i, t}=1 \text { and Systematic Drop } & =0 \\ 0 & \text { otherwise. }\end{cases}
$$

Finally, by combining the drop variables with the variable Bad News we distinguish between anticipated and non-anticipated price drops. An Anticipated Bank Drop is a Bank Drop that coincides with the arrival of bad news whereas a Non-anticipated Bank Drop is a Bank Drop that does not coincide with the arrival of bad news: ${ }^{34}$

$$
\begin{aligned}
& \text { Anticipated Bank Drop }_{i, t}= \begin{cases}1 \text { if } \text { Bank }_{\text {Drop }}, t, t & =1 \text { and Bad News } \\
i, t & =1 \\
0 & \text { otherwise. }\end{cases} \\
& \text { Non-anticipated Bank Drop }{ }_{i, t}=\left\{\begin{array}{cc}
1 & \text { if Bank } \text { Drop }_{i, t}=1 \text { and Bad News } \\
0 & \text { otherwise. }
\end{array}\right.
\end{aligned}
$$

Similarly, we split Non-anticipated Bank Drops into Non-anticipated Systematic Bank Drops and Non-anticipated Idiosyncratic Bank Drops.

\footnotetext{
${ }^{34}$ In Online Appendix, we also use an alternative specification of "bad news" that excludes generalized (across all banks) analysts' earnings revisions events as anticipating because these are likely to be associated with market wide news and thus less predictable. As expected, the evidence of price support trading ahead of anticipating price drops is stronger under this alternative specification.
} 
To analyze price support around new equity issues when the bank is under selling pressure, we additionally define a dummy variable Sell which takes a value 1 when the lag median analysts' recommendation is above 2.5 , and zero otherwise. ${ }^{35}$

In order to analyze the trading patterns of affiliated mutual funds both before and after the events, we eliminate events that take place in the first quarter or in the last quarter of the sample (or the first (last) quarter in which a bank is included (excluded) from the analysis). To avoid contaminating results by the process of banking mergers, we also exclude events in a onequarter window around bank mergers and acquisitions.

\section{Results}

We start by presenting some summary statistics and by comparing trading patterns of affiliated and non-affiliated funds and groups. Then we report results for Hypotheses (1) through (3).

\subsection{Summary statistics}

The summary statistics for funds are reported in Panel A of Table 4. Affiliated funds are two times the size of non-affiliated funds. The average AUM for affiliated funds is 123.41 million EUR whereas it is 60.21 million EUR for non-affiliated funds. Affiliated funds also belong to much larger fund families. Whereas the average fund family AUM for the affiliated funds is 6,042.55 million EUR, it is 1,698.77 for non-affiliated funds. Affiliated funds are also

\footnotetext{
${ }^{35}$ According to IBES, low analysts' recommendations stand for "buy" whereas high recommendations stand for "sell" on a scale from 1 to 5 .
} 
slightly less expensive on average, perform somewhat better in terms of (not risk-adjusted) net returns, and tend to have larger net flows.

Aligned with the differences in size, affiliated funds hold more of the parent bank. While the average for the affiliated funds is 8.26 million EUR, it is 3.59 million EUR for non-affiliated funds. Interestingly, the average change in holdings of banking stocks is slightly negative for both affiliated funds and non-affiliated funds. This means that in historical terms Spanish funds have reduced the percentage of Spanish bank outstanding shares in their portfolios.

The general patterns from the fund level carry over to the group level, as reported in Panel B of Table 4. Affiliated groups are much bigger than non-affiliated groups and hold much more of the parent bank. In line with the funds evidence, affiliated and non-affiliated groups decreased exposure to the banking stocks in the sample period.

[Insert Table 4: Summary statistics]

Next we report the initial evidence on the distribution of events (see top of Table 6). Altogether, we have 322 bank-quarter observations. As detailed in the Appendix B, we identify 12 secondary equity issues, which are not motivated by bank acquisitions. Half of them, 6 out of 12, coincide with the analysts' sell recommendations. Based on our definition of Bad News, 28 bank-quarters are associated with negative revisions in earnings forecasts. Intersecting these events with our definition of large price drops, we identify 16 Bad News periods that do not coincide with a Bank Drop and 12 Anticipated Bank Drops. Further, we identify 68 Nonanticipated Systematic Bank Drops and 23 Non-anticipated Idiosyncratic Bank Drops. We present and discuss the summary statistics for trading of affiliated and non-affiliated funds (groups) around these events along with our pooled panel regression results in Section 6.3. 


\subsection{Preliminary inquiry into trading patterns of affiliated funds/groups}

Here we present initial evidence on the trading patterns of funds and groups with all banking stocks versus the parent bank. To check for a momentum versus a contrarian style of trading, we relate changes in holdings to past banks' returns. In order to assess whether trades are informative, we test whether changes in holdings predict future banks' returns. ${ }^{36}$ To analyze how trades relate to public information on banks' valuation and operating performance, we relate changes in holdings to changes in analysts' recommendations and changes in analysts' earnings forecasts.

We use a modified version of our pooled regression model:

$$
\begin{aligned}
\Delta H_{f, i, t}= & \beta_{0}+\beta_{1} \text { BANK }_{f, i, t}+\beta_{2} \text { AFFIL }_{f, i, t}+\delta_{1} X_{i, t}+\delta_{2} X_{i, t} \times \text { BANK }_{f, i, t}+ \\
& \delta_{3} X_{i, t} \times \text { AFFIL }_{f, i, t}+\gamma \operatorname{CONTROLS}_{f, i, t}+\varepsilon_{f, i, t},
\end{aligned}
$$

where $X_{i, t}$ is either bank $i$ lagged quarterly return $\operatorname{Ret}_{i, t-1}$, bank $i$ future quarterly return $\operatorname{Ret}_{i, t+1}$, bank $i$ changes in analysts' recommendations $\triangle R E C_{i, t}$, or bank $i$ changes in analysts' earnings forecasts $\triangle A E F_{i, t}$. The estimated parameter on the interaction term $X_{i, t} * B A N K_{f, i, t}$ captures how funds affiliated to banks trade with all the banking stocks. The estimated parameter on the interaction term $X_{i, t}{ }^{*} A F F I L_{f, i, t}$ captures the differential trading of affiliated funds with the parent bank. When analyzing evidence at the group level we replace fund holdings with group holdings, and make appropriate changes in the control variables.

We start by analyzing evidence at the fund level reported in Table 5 . When trading with all banking stocks, bank-affiliated funds appear to be pure momentum traders. The estimated

\footnotetext{
${ }^{36}$ Note that the relationship between trades and concurrent returns is contaminated by the price impact of trades: positive correlation between changes in holdings and concurrent returns can be due to momentum trading (with or without price impact) or contrarian trading with price impact (effective price support); negative correlation between changes in holdings and concurrent returns is consistent with contrarian trading (with or without price impact). In untabulated results we find a positive, but insignificant association between contemporaneous returns and changes in holdings of both affiliated and non-affiliated funds.
} 
parameter on the interaction term $\operatorname{Ret}_{t-1} * B A N K$ in Column (1) is positive at 1.86 and significant with the t-statistic of 3.00. In Column (2) we also note that the estimated parameter on the interaction term $\operatorname{Ret}_{t+1} * B A N K$ is positive at 1.05 and significant with the $t$-statistic of 2.61 . The latter suggests that trades of banking funds are in general informative about future (raw) banks' returns. With respect to analysts' information, as reported in Column (3), we find that bankaffiliated funds increase their holdings when recommendations improve as the estimated parameter on the interaction term $\triangle R E C_{t}{ }^{*} B A N K$ is negative at -0.73 and significant with the $t$ statistic of -2.51 . Finally, in Column (4), we note that bank-affiliated funds also increase their holdings with the improved analysts' earnings forecasts. The estimated parameter on the interaction term $\triangle A E F_{t}{ }^{*} B A N K$ is positive at 1.82 , although insignificant with the $t$-statistic of 1.57.

When it comes to the differential trading in the parent bank stock, however, we observe a diametrically opposite trading strategy. Trades of funds in the parent bank stock, in line with the implications of our hypotheses, are consistent with the contrarian style of trading. The estimated parameter on the interaction term $\operatorname{Ret}_{t-1} * A F F I L$ in Column (1) is negative at -1.93 and significant with the t-statistic of -3.23 . We also note that the estimated parameter on the interaction term $\operatorname{Ret}_{t+1} * A F F I L$ in Column (2) is negative at -0.60 , although insignificant with the $t$-statistic of -1.01 . The latter suggests that trades of affiliated-banking funds are not informative about future (raw) returns on the parent bank. ${ }^{37}$ With respect to analysts' information, as reported in Column (3), funds decrease their holdings in the parent bank when recommendations improve as the estimated parameter on the interaction term $\triangle R E C_{t}{ }^{*} A F F I L$ is positive at 1.68 and significant with the t-statistic of 2.65. Finally, as reported in Column (4), funds decrease their

\footnotetext{
${ }^{37}$ We further analyze the issue of predictability in Section 7.3.3 when testing for predictability associated to trades related to price support.
} 
holdings in the parent bank with the improved analysts' earnings forecasts. The estimated parameter on the interaction term $\triangle A E F_{t}^{*} A F F I L$ is negative at -2.70 and significant with the $t$ statistic of -2.16 .

At the group level, all the estimated parameters have the same sign and economic interpretation as at the fund level. The number of observations at the group level, however, is substantially smaller than at the fund level, and this decreases somewhat the statistical significance.

[Insert Table 5: Preliminary inquiry into trading behavior of funds/groups]

The above evidence clearly indicates that banking funds/groups follow a different strategy when it comes to trading with the parent bank. We next explore our hypotheses that these differences relate to trading to support the price of the parent bank.

\subsection{Hypotheses testing at the fund level}

We report all the results for hypotheses testing at the fund level in Table 6. The upper part of the table elaborates on the definition of the events; the middle part reports unconditional changes in holdings in the parent bank stock around the identified events for affiliated funds $(A F F I L=1)$ and non-affiliated banking funds $(B A N K=1$ and $A F F I L=0)$; and the lower part of the table reports results for our pooled regression model.

In Column (1) we first establish that, unconditionally, when analyzing trading in all bankquarters, banking funds trade no differently when it comes to trading with the parent bank. In particular, the average change in holdings is close to zero for both affiliated and non-affiliated banking funds, slightly negative for affiliated funds and slightly positive for non-affiliated 
banking funds. The estimated parameter on variable AFFIL is negative, but small and insignificant with the $t$-statistic of -0.40 . Next we test Hypotheses (1) through (3).

Hypothesis (1): Corporate events. According to this hypothesis, price support trading takes place at the time of banks' seasoned equity offerings, and is especially strong when new equity issues coincide with selling pressure upon the parent banks' shares.

We first test for price support trading around all identified equity issues. We define our variable EVENT as a binary variable that takes the value one for the quarter in which a bank issues equity, and zero otherwise. The results are reported in Column (2). In line with our hypothesis, we note that affiliated funds are buying while non-affiliated funds are selling the parent bank at the time of new equity issues. In particular, the average change in holdings for affiliated funds is 0.08 while it is -0.32 for non-affiliated funds. Accordingly, in our regression model, the estimated parameter on the interaction term EVENT*AFFIL is positive at 0.54 and significant with the $t$-statistic of 1.99 .

Next, we analyze price support activity around equity issues that coincide with the overall selling pressure upon the banks' shares. We define our variable EVENT as a binary variable that takes the value one for the quarter in which a bank issues equity and analysts recommend selling the bank's shares $($ Sell=1), and zero otherwise. The results are reported in Column (3). In this case, the asymmetry between changes in holdings of affiliated and non-affiliated funds is even more pronounced. In particular, the average change in holdings for affiliated funds is 0.63 while it is -0.34 for non-affiliated funds. Also, the estimated parameter on the interaction term EVENT*AFFIL is higher at 1.14 and more significant with the t-statistic of 3.51 . Thus, price support around new equity issues is indeed the strongest in times when it is most needed. 
Hypothesis (2): Price impact. According to this hypothesis, price support trading coincides with the arrival of bad news about the parent bank and is especially strong when arrival of bad news does not coincide with a drop in the price of the parent bank.

To test this hypothesis, we first define our variable EVENT as a binary variable that takes a value 1 when Bad News = 1, and zero otherwise. As we can see in Column (4), affiliated funds are indeed buying the parent bank at the time of bad news, whereas non-affiliated banking funds are selling. The average change in holdings in the parent bank for affiliated funds is 0.49 and the average change in holdings for non-affiliated banking funds is -0.33 . Accordingly, in our regression model, the estimated parameter on the interaction term EVENT*AFFIL is positive at 0.93 and significant with the $t$-statistic of $4.37 .^{38}$

Next we test for price support in times when bad news about the parent bank does not coincide with large price drops. We re-define our variable EVENT as a binary variable that takes a value 1 when Bad News $=1 \&$ Bank Drop = 0, and zero otherwise. As reported in Column (5), in line with our hypothesis, buying of the parent bank by affiliated funds is especially strong when arrival of bad news does not coincide with a large price correction. The average change in holdings in the parent bank for affiliated funds is 0.83 whereas it is -0.21 for non-affiliated banking funds. In our regression model, the estimated parameter on the interaction term EVENT*AFFIL increases to 1.21 and remains highly significant with the $t$-statistics of 4.08 , despite the reduced number of events. ${ }^{39}$

Hypothesis (3): Price drops and incentives for price support. According to this hypothesis, price support trading takes place before anticipated price drops and after nonanticipated price drops. Furthermore, if price support trading is mainly driven by managers'

\footnotetext{
${ }^{38}$ In Online Appendix, we show that price support interventions are increasing with the severity of bad news.

${ }^{39}$ Again, we show in Online Appendix that price support interventions are increasing with the severity of bad news and price drops.
} 
incentives, price support trading should be stronger after non-anticipated idiosyncratic price drops. If price support trading is mainly driven by shareholders' incentives, however, price support trading should be stronger after non-anticipated systematic price drops.

We first analyze how funds trade before anticipated price drops. In particular, we redefine our variable EVENT as a binary variable that takes a value of 1 in the quarter with an Anticipated Bank Drop (Column 6), and zero otherwise. We then test for trading in the quarter before the event. We note that affiliated funds are indeed buying ahead of anticipated price drops. In particular, the average change in holdings for affiliated funds before anticipated price drops is positive at 0.59 , while it is negative at -0.77 for non-affiliated banking funds. So, in our regression model, we find that the estimated parameter on the BEFORE-EVENT*AFFIL is positive at 1.27 and significant with the $t$-statistic of 3.40 .

Next, we test for trading after non-anticipated drops. We now define our variable EVENT either as a binary variable that takes a value of 1 in the quarter with a Non-anticipated Systematic Bank Drop (Column 7) or Non-anticipated Idiosyncratic Bank Drop (Column 8), and zero otherwise. We then test for trading in the quarter after such events. We note that affiliated funds are buying after both types of non-anticipating drops. Buying after non-anticipated idiosyncratic drops, however, is much more pronounced. Whereas the average change in holdings for affiliated funds after non-anticipated systematic drops is 0.01 , it is 0.64 after non-anticipated idiosyncratic drops. In comparison, non-affiliated funds are selling after both types of price drops. The average change in holdings for non-affiliated banking funds after non-anticipated systematic price drops is -0.30 and it is -0.64 after non-anticipated idiosyncratic price drops. Accordingly, in our regression model, we find that the estimated parameter on the AFTER-EVENT*AFFIL is much larger for trading after idiosyncratic price drops. It is 0.44 for trading after systematic price drops 
and 1.68 for trading after idiosyncratic price drops. Both are significant with the $t$-statistics of 2.65 and 3.58 .

All in all, the evidence suggests that price support activity is much more pronounced around idiosyncratic price drops. This suggests that price support interventions are largely driven by bank managers' incentives due to peer competition.

[Insert Table 6: Hypotheses testing at the fund level]

\subsection{Hypotheses testing at the group level}

Next we test all the hypotheses at the banking group level. Results are reported in Table 7. All the estimated parameters have the same sign and economic interpretation as at the fund level. The number of observations at the group level, however, is substantially smaller than at the fund level, and this influences the statistical significance.

[Insert Table 7: Hypotheses testing at the group level]

\subsection{Reverse engineering}

Our approach so far has been first to define events and then to analyze trading patterns of affiliated and non-affiliated mutual funds around those events. Now we reverse the exercise and deduct price support activity of mutual funds by identifying periods when affiliated funds are buying shares of their own bank while other banking funds are selling.

While it is difficult to test all our hypotheses with the reverse engineering exercise, we focus on the main considerations for price support around crisis periods. Following our hypotheses, the differential trading between the funds affiliated with the parent bank and other banking funds should occur especially before the arrival of bad news to prevent share price of the 
parent bank from dropping and after price drops to speed up price recovery. The differential trading should also boost returns in the concurrent quarter, if price support is at least partially effective. Hence, we should expect that the degree of asymmetric trading is (i) negatively related to future revisions in analysts' earnings forecasts of the parent bank, (ii) negatively related to past returns of the parent bank, and (iii) positively related to current returns of the parent bank.

We perform the analysis at the highest level of aggregation, the group level. To focus on the trading patterns of banking funds, we exclude non-banking groups. ${ }^{40}$ In order to guarantee comparability of results with the main analysis, we use the same time period from 1996Q2 to 2009Q2 and we exclude observations in a one-quarter window around bank mergers. ${ }^{41} \mathrm{We}$ consider cases in which the holdings of non-affiliated banking groups decrease and the holdings of the affiliated banking groups simultaneously increase by more than $0.0125 \%, 0.0250 \%$, $0.0500 \%$, and $0.1000 \%$. We then compute the average change in analysts' earnings forecasts and the returns of the parent bank stocks around those episodes of asymmetric trading activity.

Results are reported in Table 8 . We first note a clear negative relation between the intensity of asymmetric trading and future changes in analysts' earnings forecasts. While the average change in future earnings forecasts is $-0.32 \%$ when we consider all bank-quarter observations, it decreases to $-7.32 \%$ for the case with the most asymmetric trading. Next, we note that intensity of asymmetric trading is negatively related to past bank returns. While the average lagged quarterly return is $2.20 \%$ when we consider all bank-quarter observations, it

\footnotetext{
${ }^{40}$ Non-banking groups are very diverse and different from banking groups (for example, some of these groups are new and by construction have to build up their portfolio). Thus, the imposed condition that non-affiliated groups are selling is very restrictive when we include all groups. For this reason, in the main analysis in this section we exclude non-banking groups. In untabulated results we perform the analysis including non-banking groups while weakening the trading asymmetry condition (we allow non-affiliated groups to buy small amounts of the banks). The results are qualitatively identical to the ones reported here.

${ }^{41}$ Originally holdings data run from 1995Q1 through 2009Q3. We exclude year 1995 to calculate funds' lagged annual returns. We also eliminate events in the first and the last quarter to guarantee comparability of the sample across different hypotheses.
} 
monotonically decreases to $-18.70 \%$ for the case with the most asymmetric trading. Finally, the intensity of asymmetric trading is positively related to contemporaneous returns. While the average quarterly return is $2.21 \%$ when we consider all bank-quarter observations, it increases to $10.87 \%$ for the case with the most asymmetric trading.

Note that positive returns in the concurrent quarter cannot be explained by the arrival of positive news as the concurrent changes in the analysts' earnings forecasts of the parent bank are always negative and strongly negatively correlated with the concurrent returns. All in all, the reverse engineering exercise is conclusive in providing additional support for the price support hypotheses.

[Insert Table 8: Reverse engineering]

\subsection{Economic significance}

The main goal of price support trading is to temporarily inflate returns. Above we document that price support trading is present when the arrival of bad news does not materialize in negative price corrections. Reverse engineering exercises confirm that the stronger the price support activity, the larger the concurrent returns (even in the presence of bad news about the parent bank).

Now we aim to provide an estimate of the economic significance of price supporting activity. Given that all the banks in Spain have asset management arms, and therefore we lack a clearly defined control sample, we proceed as follows.

For episodes of price support, we first compare returns on the parent bank with the mean returns of all other banks. To account for banks' riskiness, we next conduct an event analysis. Starting with monthly data and a backward-looking rolling window of 60 months, we estimate 
the CAPM and the 4-factor (three Fama and French factors plus a momentum factor) models. ${ }^{42}$ We then use the estimated alphas and the factor loadings to calculate one-month ahead abnormal returns for each bank in the sample. We use the General Madrid index as a proxy for the market. Because the obtained data on the rest of the risk factors is expressed in logarithms, we conduct the analysis in logarithmic returns. ${ }^{43}$ For episodes of price support, we sum up abnormal monthly returns within each bank-quarter. To calculate economic gains in EUR terms, we multiply abnormal monthly returns with the corresponding market values of banks and sum up the product within each bank-quarter.

Table 9 reports the corresponding summary statistics for the quarters with the strongest price support activity as defined in the reverse engineering exercise. We focus on price support activity as defined in the reverse engineering exercise rather than the no-drop events defined in the Hypothesis 2 because in the latter case we impose no price drop condition, and we may therefore upward bias the economic significance of the results. ${ }^{44}$

We first note that the average difference between the log returns on the supported banks and the returns on all the other banks is always positive and increases monotonically with the degree of asymmetric trading, as reported in Panel A. The return difference is $0.29 \%$ for the weakest criteria of asymmetric trading and increases to $6.71 \%$ for the strongest case of the asymmetric trading.

In line with the return differences, we also find that the average abnormal returns are positive and generally increase with the degree of asymmetric trading. Abnormal returns are slightly higher than simple return difference in the weakest case of the asymmetric trading, but

\footnotetext{
${ }^{42}$ We thank Rafael Santamaria for providing the size, value, and momentum factors for the Spanish market.

${ }^{43}$ Using raw returns rather than logarithmic returns changes some of the estimates, but preserves the main conclusions.

${ }^{44}$ Untabulated results show that economic significance for no-drop events defined in the Hypothesis 2 is at least one order of magnitude higher.
} 
substantially lower in the strongest case of the asymmetric trading. Also, as expected, abnormal returns are higher within the CAPM pricing model than within the Fama and French plus momentum model. In terms of the CAPM, abnormal returns vary between $0.73 \%$ and $3.49 \%$ per bank-quarter. In terms of the Fama and French plus momentum model, abnormal returns vary between $0.39 \%$ and $2.97 \%$ per bank-quarter.

In Panel B we next report average gains in terms of the total market value of banks. Again, the results depend on the particular asset pricing model and the degree of asymmetric trading. In total the estimated gains vary between 39.49 and 367.91 million EUR per bankquarter. Summing up over all the bank-quarters for a given level of asymmetric trading, as reported in Panel C, total gain estimates vary between 1.30 and 7.17 billion EUR.

[Insert Table 9: Economic significance]

\section{Further inspection of the price support hypothesis}

In this section, we further explore the price support hypotheses developed in this paper. First, we analyze implications of the theory for the cross-section of funds. Second, we test for overweighting in the parent bank stock in affiliated funds portfolios. Finally, we balance the price support hypothesis against alternative hypotheses of fund trading.

\subsection{Price support and the cross-section of funds}

As discussed in Section 3.2, price support trading may be beneficial to the controlling company, but it can deteriorate performance of the price-supporting funds. This may reduce the revenue from performance fees as well as fixed fees (if net-flows depend on funds' performance). Funds' fee structure may therefore importantly affect the degree of funds' price supporting trading. Performance fees deter any non-value maximizing trades. Loads (especially 
back-end loads or exit fees) discourage redemptions (Chordia, 1996). Therefore, in the crosssection of funds, we may expect price support trading to be stronger among funds that do not charge performance fees and charge exit fees.

To gain some insights into the price support interventions in the cross-section of funds, we re-run all the tests for our hypotheses including only funds that charge exit fees and no performance fees. The dual restriction on the fees reduces the number of observations substantially (by approximately 65\%). As expected, however, we observe in untabulated results that the estimated parameters on all the interactive terms of interest increase. The average increase in terms of the estimated parameters is $25 \%$. The standard errors on the estimated parameters, however, are too big to reject the hypothesis that the estimated parameters in the filtered sample of funds are different from the ones in the non-filtered sample of funds. We interpret this as suggestive corroborating evidence that funds' fee structure plays a role for price support interventions in the cross-section of funds.

\subsection{Lack of incentives for overweighting}

The documented trading patterns suggest that controlling banks in Spain can influence the investment decisions of the affiliated funds. Rather than providing price support, however, as discussed in the introduction, bank managers could use their affiliated funds to gain friendly votes in General Meetings, along the lines of Cohen and Schmidt (2009) and Davis and Kim (2007). Similarly, we could expect that bank-affiliated funds overweight the stock of the parent bank.

In Spain, however, the market for corporate control is rather weak, as discussed in Section 5.1. The existence of large controlling shareholders and the accomodating nature of the 
General Meetings tend to mitigate incentives to use affiliated funds holdings in the parent bank for governance issues.

To check for overweighting, we estimate a version of model (1) where the dependent variable is the portfolio holdings $H$ instead of the change in portfolio holdings $\Delta H$ :

$$
H_{f, i, t}=\beta_{0}+\beta_{1} B A N K_{f, i, t}+\beta_{2} A_{F F I L} L_{f, i, t}+\gamma \operatorname{CONTROLS}_{f, i, t}+\varepsilon_{f, i, t},
$$

The results at both the fund and the group level are reported in Table 10. The evidence on overweighting is mixed. The estimated parameter on the variable AFFIL is positive at 2.22 and significant with a $t$-statistic of 2.84 at the fund level, but becomes insignificant at 57.89 and $t$ statistics of 1.56 at the banking group level. Also, we note in untabulated results that the fund level results are not robust to exclusion of zero holdings or using logarithms of holdings (as in Cohen and Schmidt, 2009). We therefore conclude that there is no conclusive evidence on overweighting of the parent bank by the affiliated funds, consistent with a weak motive for such a practice in the Spanish market.

[Insert Table 10: Holdings in the parent bank]

\subsection{Discussion on alternative explanations}

We document several trading patterns that are consistent with affiliated funds trading to support the price of the parent bank. Affiliated funds are buying the parent bank at the time of new equity issues, at the arrival of bad news, before anticipated price drops, and after nonanticipated systematic and idiosyncratic price drops. Below we discuss how these documented trading patterns differ from other trading strategies.

\subsubsection{Price support versus trading to reduce volatility}


Price support around crisis periods is aimed at reducing the downside potential of the stock price and could be seen as one leg of volatility reduction. Given that funds cannot hold unrestricted amounts of the parent bank, and therefore occasionally need to download their accumulated holdings in non-crisis periods, price support trading may also induce trading that reduces the upside potential of the stock price. ${ }^{45}$ In this sense, price support is related to trading to reduce volatility. It goes beyond such strategy, however, because trading to reduce volatility does not differentiate between systematic and idiosyncratic shocks, and has no implications for trading around special corporate events. Also, unlike price support, trading to reduce volatility has symmetric implications for price drops and price jumps.

To check for the symmetry between trading around price drops and price jumps, we repeat all the tests of Hypotheses (3) for the case of price jumps. We define variables Good News, Bank Jump, and Systematic Bank Jump by reverting inequality signs in Eq. (5) through Eq. (7):

$$
\begin{array}{r}
\text { Good News }(a)_{i, t}=\left\{\begin{array}{lr}
1 & \text { if } \Delta A E F_{i, t}>a \\
0 & \text { otherwise. }
\end{array}\right. \\
\text { Bank Jump }(b)_{i, t}= \begin{cases}1 & \text { if } r_{i, t}-\bar{r}_{i, t-1}>b \sigma_{i, t-1} \\
0 & \text { otherwise }\end{cases} \\
\text { Systematic Jump }(b)_{t}= \begin{cases}1 & \text { if } r_{M, t}-\bar{r}_{M, t-1}>b \sigma_{M, t-1} \\
0 & \text { otherwise, }\end{cases}
\end{array}
$$

To preserve symmetry, we set $a$ to 0.050 , and $\mathrm{b}$ to 0.50 .

The results at both the fund and the group level are reported in Table 11. If affiliated funds were trading to reduce volatility of the parent bank, we should observe that affiliated funds are selling the stock of the parent bank before anticipated price jumps and after non-anticipated

\footnotetext{
${ }^{45}$ As a general rule, Spanish funds cannot invest more than 5\% of their capital (NAV) in securities issued by a single issuer.
} 
price jumps. Insofar as trading to reduce volatility is restricted to the parent bank, we should also observe differences between trades of affiliated and non-affiliated banking funds.

The affiliated funds, however, are buying the stock of the parent bank before anticipated price jumps and after non-anticipated systematic price jumps. The only case when we observe that affiliated funds are selling the parent bank is after large idiosyncratic jumps. ${ }^{46}$ Furthermore, both non-affiliated and affiliated funds/groups always trade in the same direction. Although magnitudes of trades differ somewhat, none of the estimated parameters on the interaction terms of interest are significant, neither at the fund level nor at the group level. We thus conclude that the evidence of trading around price jumps is inconsistent with trading to reduce volatility.

[Insert Table 11: Trading around price jumps]

\subsubsection{Price support versus momentum, contrarian, and timed trading}

Price support trading around crisis periods is also inconsistent with momentum, contrarian, and timed trading. First, it cannot be rationalized by momentum trading because such a strategy would imply selling after price decreases, yet we find that affiliated funds are buying after non-anticipated price drops.

Second, the documented trading patterns also differ from the contrarian style of trading. Although buying after non-anticipated price drops (and downloading of accumulated holdings in non-crisis periods) makes affiliated funds look like contrarians when trading with the parent bank, there are distinct differences between contrarian trading and price support. First, a

\footnotetext{
${ }^{46}$ Broadly speaking, trades around idiosyncratic jumps are consistent with timed trading strategy (buying before price jumps and selling after price jumps).
} 
contrarian strategy does not differentiate between idiosyncratic and systematic shocks. Second, a contrarian strategy has no implications for special corporate events. Third, although a contrarian strategy implies buying after a price decrease, any unhedged buy order can only be rationalized with the expectation of a future price increase. However, we find that affiliated funds are buying the parent bank stock in anticipation of price drops. For the same reason the documented trading patterns cannot be part of a timing strategy because buying in anticipation of price drops corresponds exactly to the opposite of timed trading.

To support the claim that buying after non-anticipated drops makes affiliated funds appear to follow a contrarian style of trading, we repeat the exercise from Section 6.2. In Table 5, Column (1) we report that trades of affiliated funds are overall negatively related to lagged returns, consistent with the contrarian style of trading. Now we control for trading after nonanticipated drops, and find that the estimated parameter on lagged returns increases from -1.93 to -1.41 and the associated $t$-statistic goes from highly significant at -3.23 to marginally significant at $-1.84 .{ }^{47}$ Thus, although the estimated parameter on the lagged returns is still negative, it is smaller and less significant, which supports the notion that the seemingly contrarian style of trading is to an extent driven by price support trading.

\subsubsection{Price support versus superior information}

Finally, we test whether the documented price supporting trades contain superior information. In Section 6.2 we document that trades of affiliated funds in general do not predict the quarterly returns on the parent bank. However, it could be that the documented price supporting trades contain superior information and that such information lives over longer

\footnotetext{
${ }^{47}$ At the group level, the estimated parameter increases from -38.77 to -13.71 and the $t$-statistic increases from -1.15
} to -0.33 . 
horizons. To test for this, we follow Cohen and Schmidt (2009) and test for predictability of annual returns. Essentially, we repeat the exercise from Section 6.2 while including all interaction terms between future annual returns, our event variable EVENT, banking dummy $B A N K$, and affiliation dummy AFFIL. We focus our attention on the interaction term EVENT*Ret $t_{t+1} * A F F I L$, which captures the extent to which trades of affiliated funds exhibit superior information about the future returns on the parent bank relative to other funds and nonevent quarters. If price supporting trades of affiliated funds contain superior information, the coefficient should be positive and significant. Because different hypotheses imply that price supporting trading occurs at different times around the events, we pool together separately cases when price support trading occurs before the event, during the event, and after the event.

Results at both the fund level and the group level are reported in Table 12. In Column (1) and (5) we first follow up on evidence from Section 6.2 and show that trades with the parent bank in general do not predict future annual returns. The estimated parameter of interest is negative and insignificant at both the fund and the group level with t-statistics of -1.23 and -0.72 , respectively.

Focusing on price supporting trades, we note that all the trades are negatively related to future annual returns at both the fund level and the group level. Moreover, in the case of beforeevent and during-event fund level price supporting trades, the estimated parameters of interest are significant with $t$-statistics of -3.29 and -2.21 , respectively. The estimated parameter of interest is also significant with the t-statistic of -1.97 in the case of during-event trades at the group level. Thus the evidence overall suggests that price supporting trades do not contain superior information.

[Insert Table 12: Superior information] 


\section{Conclusion}

Fund managers have two principals: the fund's investors, and the owners of the asset management firm. The interests of these two principals are not necessarily aligned, and the interest of the latter may prevail. We focus on a specific case of Spanish financial conglomerates, and show that this conflict of interest may lead to bank-affiliated mutual funds trading consistent with supporting the price of the parent bank.

We document that bank-affiliated mutual funds systematically increase their holdings in the controlling bank stock around seasoned equity issues, at the arrival of bad news about the parent bank, in anticipation of price drops as well as after non-anticipated price drops. Because interventions after non-anticipated price drops are concentrated around idiosyncratic shocks rather than systematic shocks, we conclude that bank managers' incentives due to peer competition are the main factor behind the documented trading patterns. The estimated gain for the period 1996-2009 in terms of the market value of the banks varies between 1.30 and 7.17 billion EUR. The results thus imply that the ownership of asset management companies matters because it creates a new motive for trading, with direct impact on asset prices.

Our paper contributes to the growing literature on conflicts of interest in financial institutions. We document a case where self-imposed controls and regulations in place are insufficient to mitigate the economic impact of conflicts of interest. Although we focus on a specific case of Spanish financial conglomerates, there are many other areas of finance where price support activities could naturally arise. Funds affiliated with any entity (other than the bank) could be trading the entity's stock in a similar fashion. Trading to support prices may also spread to other companies in which these entities have an interest. Furthermore, similar trading 
patterns can be present in the management of pension plan assets or in foundations where price support could benefit the funding parties. Because countries have different levels of regulation and investor protection, the effectiveness of regulation and self-imposed controls could be measured by a cross-country analysis of price support activities. 


\section{Appendix A. Definition of control variables}

Our set of control variables at the fund level includes:

- $\quad R E C_{i, t}:$ Median of analysts' recommendations for bank $i$ in quarter $t$.

- NETFLOW $W_{f, t}$ : Standardized net flows of fund $f$ in quarter $t$. Given that the CNMV provides data on inflows and outflows only from April 1999 onwards, we compute net flows using fund assets under management $A U M_{f, t}$ and net returns $r_{f, t}$. As is standard in the literature, we standardize net flows by the funds' lagged assets under management:

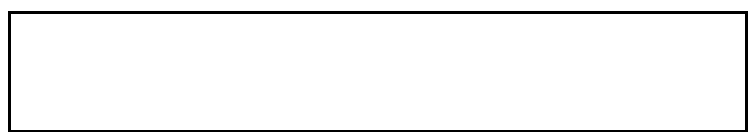

Robustness tests in Appendix C using actual inflows and outflows for 1999Q2-2009Q3 show that the results hold true in this subsample.

- $\quad A U M_{f, t}:$ Assets under management of fund $f$ in quarter $t$. They are reported monthly in the data set. We take the last month of the quarter figure and express it in millions of euros.

- $\quad \operatorname{AUM}(F F)_{F, t}:$ Assets under management of the fund family $F$ in quarter $t$. This is obtained by adding up all the $A U M$ of funds in fund family $F$.

- $\quad L A G R E T_{f, t}$ : Fund $f^{\prime}$ s lagged annual return in quarter $t$. It is computed using the change in funds' $N A V$ during the previous year. Formally:

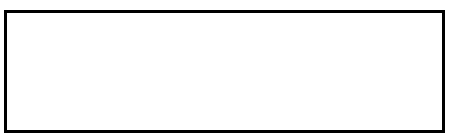

- $\quad F E E S_{f, t}$ : Fund $f$ fees in quarter $t$. The data set provides management fees, performance fees, custodian fees, up-front fees, redemption fees, and rebate fees. All the fees are reported monthly in annual percentages. In our construction of the fee variable we follow Sirri and Tufano (1998). Unfortunately, the data set does not report funds' expense ratio. For this reason we express fees in terms of the percentage derived from the previous fees 
taking the last month of the quarter figure. Performance fees are included only when the fund has a positive return for the year. More specifically, we compute the fee variable as follows: ${ }^{48}$

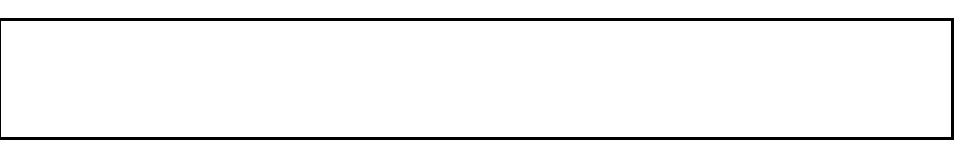

- $\quad S T Y L E_{f, t}$ : Fund $f$ style of investment in quarter $t$. Unfortunately, the fund style is only reported from 1999Q2 onward. For this reason, we do not include it in the main analysis, although in robustness tests in Appendix $\mathrm{C}$ the results survive in the subsample starting in 1999Q2 when the funds' style is included as a control variable. We select the fund style as reported in the last month of each quarter.

- Time dummies: All the regressions include yearly dummies.

At the group level, we redefine fund related control variables as:

- $\quad N E T F L O W_{G, t}$ is the sum of the funds' netflow $N E T F L O W_{f, t}$ for all the funds that belong to group $G$ at time $t$.

- $A U M_{G, t}$ is the sum of the funds' assets under management $A U M_{f, t}$ for all the funds that belong to group $G$ at time $t$.

- $\operatorname{LAGRET}_{G, t}$ is the assets under management weighted average of funds' lagged returns $\operatorname{LAGRET}_{f, t}$ for all the funds that belong to group $G$ at time $t$.

- $F E E S_{G, t}$ is the assets under management weighted average of funds' fees $F E E S_{f, t}$ for all the funds that belong to group $G$ at time $t$.

\footnotetext{
${ }^{48}$ Any missing fee in the Spanish SEC data set is reported as the value 99.99. In these cases, we use the average of the minimum and maximum fees reported.
} 


\section{Appendix B. Determination of dates for equity issues of Spanish listed companies}

There is no data set that reports all equity issues of Spanish listed companies for the period of our analysis. Thus, we proceed along the lines of Stephens and Weisbach (1998) and infer equity issue dates from the evolution of the outstanding shares as calculated using the data from Datastream. To make sure that all capital increases identified in Datastream correspond to actual equity issues and to classify them, we manually verify that the increase in shares outstanding was reported to the CNMV as a stock issue. In particular, for each bank in the study we define a proxy for the number of shares outstanding $N O S H$ as the ratio of market capitalization to the adjusted share price and focus on discrete jumps in which $N O S H>0$. Then we manually check the CNMV records for all these dates to match them to actual equity issues. This procedure results in a total of 23 matches of $N O S H$ increases and actual equity issues reported to the CNMV for analysis.

Some of the new equity issues are motivated by bank acquisitions, where the timing of price support depends on when the fixed or flexible exchange rates are determined (Ahern and Sosyura, 2014). Because such data does not exist for Spain, we exclude from our analysis all such equity issues. Out of 23 new equity issues, we identify 11 stock issues motivated by bank acquisitions. We thus focus on the remaining 12 new equity issues. 


\section{References}

Ahern, K., Sosyura, D., 2014. Who writes the news? Corporate press releases during merger negotiations. Journal of Finance 69, 241-291.

Baker, M., Wurgler, J., 2002. Market timing and capital structure. Journal of Finance 57, 1-32.

Benmelech, E., Kandel, E., Veronesi, P., 2010. Stock-based compensation and CEO (dis)incentives. Quarterly Journal of Economics 125, 1769-1820.

Bhattacharya, U., Daouk, H., 2002. The world price of insider trading. Journal of Finance 57, 75108.

Bergstresser, D., Philippon, T., 2006. CEO incentives and earnings management. Journal of Financial Economics 80, 511-529.

Burns, N., Kedia, S., 2006. The impact of performance-based compensation on misreporting. Journal of Financial Economics 79, 35-67.

Carhart, M., Kaniel, R., Musto, D., Reed, A., 2002. Leaning for the tape: Evidence of gaming behavior in equity mutual funds. Journal of Finance 57, 661-693.

Chevalier, J., Ellison, G., 1997. Risk taking by mutual funds as a response to incentives. The Journal of Political Economy 105, 1167-1200.

Chordia, T., 1996. The structure of mutual fund charges. Journal of Financial Economics 41, 339.

Cocco, J., Volpin, P., 2007. Corporate governance of pension plans: The U.K. evidence. Financial Analysts Journal 63, 70-83.

Cohen, L., Schmidt, B., 2009. Attracting flows by attracting big clients. Journal of Finance 64, 2125-2151.

Cinco Dias, 2003. La maldicion de los gestores estrella. Miguel Rodriguez Canfranc, July 19th.

Cremers, M., Ferreira, M., Matos, P., Starks, L., 2013. The mutual fund industry worldwide: Explicit and closet indexing, fees, and performance. Unpublished working paper. University of Notre Dame.

Crespi, R., Garcia-Cestona, M., Salas, V., 2004. Governance mechanisms in Spanish banks. Does ownership matter? Journal of Banking and Finance 28, 2311-2330. 
Davis, G., Kim, E., 2007. Business ties and proxy voting by mutual funds. Journal of Financial Economics 85, 552-570.

Diamond, D., Verrecchia, R., 1982. Optimal managerial contracts and equilibrium security prices. Journal of Finance 37, 275-287.

Dittmar, A., 2000. Why do firms repurchase stock? Journal of Business 73, 331-335.

Durnev, A., Kim, E., 2005. To steal or not to steal: Firm attributes, legal environment, and valuation. Journal of Finance 60, 1461-1493.

Ellis, K., Michaely, R., O'Hara, M., 2000. When the underwriter is the market maker: An examination of trading in the IPO aftermarket. Journal of Finance 55, 1039-1074.

Elton, E., Gruber, M., Gultekin, M., 1981. Expectations and share prices. Management Science 27, 975-987.

Ferreira, M., Keswani, A., Miguel, A., Ramos, S., 2012. The flow-performance relationship around the world. Journal of Banking and Finance 36, 1759-1780.

Financial Times, FTAlphaville, 2012. The Spanish bank buy-back riddle, David Keohane, June 26.

Frye, M., 2001. The performance of bank-managed mutual funds. Journal of Financial Research 24, 419-442.

Funds People, 2012. Salarios de gestores españoles: un asunto muy particular de cada entidad. Macarena Munoz, December 13th.

Gaspar, J., Massa, M., Matos, P., 2006. Favoritism in mutual fund families? Evidence on strategic cross-fund subsidization. Journal of Finance 61, 73-104.

Gibbons, R., Murphy, K., 1990. Relative performance evaluation for chief executive officers. Industrial and Labor Relations Review 43, 30-51.

Gil-Bazo, J., Martinez, M., 2004. The black box of mutual fund fees. Revista de Economia Financiera 4, 54-82.

Givoly, D., Lakonishok, J., 1979. The information content of financial analysts' forecasts of earnings. Journal of Accounting and Economics 1, 165-185.

Givoly, D., Lakonishok, J., 1980. Financial analysts' forecast of earnings: Their value to investors. Journal of Banking and Finance 4, 221-233. 
Gleason, C., Lee, C., 2003. Analyst forecast revisions and market price discovery. The Accounting Review 78, 193-225.

Gropp, R., Vesala, J., Vulpes, G., 2006. Equity and bond market signals as leading indicators of bank fragility. Journal of Money, Credit and Banking 38, 399-428.

Heron, R., Lie, E., 2007. Does backdating explain the stock price pattern around executive stock option grants? Journal of Financial Economics 83, 271-295.

Hong, H., Wang, J., Yu, J., 2008. Firms as buyers of last resort. Journal of Financial Economics $88,119-145$.

Holmstrom, B., 1979. Moral hazard and observability. Bell Journal of Economics 10, 74-91.

Holmstrom, B., 1982. Moral hazard in teams. Bell Journal of Economics 13, 324-340.

Imhoff, E., Lobo, G., 1984. Information content of analysts' composite forecast revisions. Journal of Accounting Research 22, 541-554.

Lakonishok, J., Shleifer, A., Thaler, R., Vishny, R., 1991. Window dressing by pension fund managers. American Economic Review Papers and Proceedings 81, 227-31.

La Porta, R., Lopez-de-Silanes, F., Shleifer, A., Vishny, R., 2000. Investor protection and corporate governance. Journal of Financial Economics 58, 3-27.

Lewellen, K., 2006. Risk, reputation, and IPO price support. Journal of Finance 61, 613-653.

Loughran, T., Ritter, J., 1995. The new issues puzzle. Journal of Finance 50, 23-51.

Loughran, T., Ritter, J., 1997. The operating performance of firms conducting seasoned equity offerings. Journal of Finance 52, 1823-1850.

Marin, J., Olivier, J., 2008. The dog that did not bark: Insider trading and crashes. Journal of Finance 63, 2429-2476.

Massa, M., Rehman, Z., 2008. Information flows within financial conglomerates: Evidence from the banks-mutual funds relation. Journal of Financial Economics 89, 288-306.

Mehran, H., Stulz, R., 2007. The economics of conflicts of interest in financial institutions. Journal of Financial Economics 85, 267-296.

Mola, S., Guidolin, M., 2009. Affiliated mutual funds and analyst optimism. Journal of Financial Economics 93, 108-137. 
Moreno, M., Rubio, G., 2007. Some insights on the behavior of the mutual fund industry in Spain, In: Gregoriou, G. (Ed.), Diversification and Portfolio Management of Mutual Funds. Palgrave-MacMillan, London, pp. 272-311.

New York Times, 2008. Citigroup reported to seek new ban on short sales. Dealbook, November 20.

Peng, L., Roell, A., 2008. Manipulation and equity-based compensation. American Economic Review Papers and Proceedings 98, 285-290.

Pool, V., Sialm, C., Stefanescu, I., 2013. It pays to set the menu: Mutual fund investment options in 401(k) plans. Unpublished working paper. Indiana University.

Prowse, S., 1997. The corporate governance system in banking: What do we know? Banca Nazionale del Lavoro Quarterly Review, March, 11-40.

Ritter, J., Zhang, D., 2007. Affiliated mutual funds and the allocation of initial public offerings. Journal of Financial Economics 86, 337-368.

Ruud, J., 1993. Underwriter price support and the IPO underpricing puzzle. Journal of Financial Economics 34, 135-151.

Schultz, P., Zaman, M., 1994. Aftermarket support and underpricing of initial public offerings. Journal of Financial Economics 35, 199-219.

Sialm, C., Tham, T., 2014. Spillover effects in mutual fund companies. Unpublished working paper. University of Texas at Austin.

Sias, R., Starks, L., Titman, S., 2006. Changes in institutional ownership and stock returns: Assessment and methodology. Journal of Business 79, 2869-2910.

Sirri, E., Tufano, P., 1998. Costly search and mutual fund flows. Journal of Finance 53, 15891622 .

Stephens, C., Weisbach, M., 1998. Actual share reacquisitions in open-market repurchase programs. Journal of Finance 53, 313-333.

Stein, G., Capape, J., Gallego, M., 2012. Corporate governance in Spanish banks: 2011. Unpublished working paper. IESE Business School.

Wall Street Journal, 2011. SocGen bids to stabilize share price. Noemie Bisserbe, August 24.

Wurgler, J., 2000. Financial markets and the allocation of capital. Journal of Financial Economics 58, 187-214. 


\title{
Online Appendix for
}

\section{Price support by bank-affiliated mutual funds}

\author{
Benjamin Golez†, Jose M. Marin
}

June, 2014

This document contains robustness checks of the results reported in Section 6.3 (Hypotheses testing at the fund level) in "Price support by bank-affiliated mutual funds". In particular, we consider several variations in the treatment of the data and specifications of price drops. We also replicate the analysis in terms of changes in portfolio weights. All the results are reported in Table A.1.

†University of Notre Dame, Mendoza College of Business; email: bgolez@,nd.edu; tel.:+1 574 631 1458, fax: +1 5746315255 .

†Universidad Carlos III de Madrid, Department of Business Economics; email: josemaria.marin@uc3m.es; tel.: +34 916249307. 


\section{Robustness Checks}

Zero holdings. In the main analysis, we include zero holdings (observations when a fund has no holdings of the analyzed bank). Now, we repeat the analysis by including only non-zero holdings. Because our focus lies on changes in holdings, we include only observations when funds' current or one quarter lagged holdings are positive. The results are reported in Panel A. The number of observations drops substantially from 230,133 to 92,249 , but the results overall become stronger both in terms of the estimated parameters and the statistical significance.

Fund mergers. In the main analysis, we mitigate the effect of banking mergers by eliminating all drops around bank mergers for all the banks involved in the mergers. We do not control, however, for mergers between funds. For this reason, we next use our hand-collected data on the funds' mergers and exclude from the analysis observations when funds are acquired by another fund. Altogether we identify 1952 fund mergers in the period 2001 to 2009 .

Excluding such observations only has a small effect on the results, as reported in Panel B. The estimated parameters of interest and the associated t-statistics are very similar to those in the main analysis.

Threshold levels for crisis periods. In the main analysis, we define Bad News in Eq. (5) by setting the threshold level $a$ to -0.05 , and we define Bank Drop and Systematic Drop in Eq. (6) and (7) by setting the threshold level $b$ to -0.5 . We now analyze the sensitivity of results to these parameter choices. Panel $\mathrm{C}$ reports results with $a$ equal to -0.025 and $b$ equal to -0.25 , and Panel D reports results with $a$ equal to -0.075 and $b$ equal to -0.75 .

The stronger the criteria for our definition of bad news and price drops, the smaller the number of identified events. The results, however, are consistent with the main analysis under both criteria. Analyzing results reported in Columns (4), we also note that the severity of bad 
news is positively related to price support interventions. Comparing results reported in Panel C and $\mathrm{D}$ (and results reported in the main analysis), we note that the estimated parameter of interest increases monotonically with the severity of bad news from insignificant at 0.168 (t-statistic of 1.15) to highly significant at 1.12 (t-statistic of 4.17). Such monotonicity of interventions holds also in the case when bad news events do not coincide with price drops. As reported in Column (5), the estimated parameter of interest increases from 0.43 (t-statistic of 2.11) to 1.72 (t-statistic of 4.38$){ }^{49}$

With respect to interventions around price drops, we note that all the estimated parameters of interest remain positive and significant. The only exception is the case of trading before anticipated crisis periods under the strong criteria. In line with the main analysis, the estimated parameters for price support trading after idiosyncratic price drops are larger than the estimated parameters for price support trading after systematic price drops under both criteria.

Madrid general SE index. In the main analysis, we measure Systematic Drop with respect to the equally-weighted average of the banking stocks in our treatment group. We now repeat the analysis using Madrid general SE Index. Most of the identified events remain the same. Thus, as reported in Panel E, the results are very comparable to the main analysis.

Drops defined in terms of absolute return. In the main analysis, we employ a rolling window approach to define price drops based on the time series of returns. Now we repeat the analysis using a simpler approach and define a Bank Drop (Systematic Drop) as a quarter in which the quarterly stock return (banking index return) is lower than $-10 \%$. The results reported in Panel F reveal that all the main results survive and are very comparable to the results reported in the main analysis.

\footnotetext{
${ }^{49}$ In untabulated results we observe similar monotonicity when we fix $a$ and vary $b$, or when we fix $b$ and vary $a$.
} 
Subsample analysis. The CNMV provides data on some fund related variables, such as investment style and flows, only from 1999Q2 onward. For this reason, we now re-estimate our model for the subperiod 1999Q2 to 2009Q3 while including the officially reported net flows (instead of our approximated net flows) and the investment style dummies. The results are reported in Panel G and are similar to the results from the full sample.

Crisis periods defined in terms of changes in the market-to-book ratio. In the main analysis, we use returns to measure crisis periods. Now we repeat the analysis using changes in the market-to-book ratio $(M K B K)$. In particular, we follow the procedure from the main analysis while replacing return data with the $M K B K$ ratios. For the banking index, we use the average $M K B K$ for all the banks in our treatment group. Then we calculate the mean and the standard deviation of the $M K B K$ for each bank in our treatment group and the banking index using 5-year rolling windows of quarterly observations. Drops are defined as in Eq. (6) and (7). We note that the results reported in Panel $\mathrm{H}$ are almost identical to the results in the main analysis. We assign this to the staleness of the book value and the fact that almost all the within-year variation in the $M K B K$ is driven by price changes.

Predictability of price drops. In the main analysis, we contend that all price drops associated with negative revisions in analysts' earnings forecasts are predictable. Some of the earnings revisions, however, may be more predictable than others. In particular, banking sector wide revision in analysts' earnings forecasts may also be triggered by external factors and thus be less predictable. For this reason, we now repeat the analysis by defining our variable Bad News as an event when negative revision in analysts' forecasts for the parent bank does not coincide with the negative revision in earnings forecasts for other banks (mean revision for all the banks in our treatment group except for the parent bank). Using as a threshold level for 
negative earnings revisions $\mathrm{a}=-0.05$, as in the main analysis, we note that 5 price drops that were previously defined as anticipated price drops are now classified as non-anticipated price drops. As reported in Panel I, the evidence for price support trading during bad news periods (that coincide or not with price drops) as well as the evidence for trading after non-anticipated price drops remains strong and significant. The results for trading ahead of anticipated price drops, however, become much stronger both in terms of the estimated parameters and the statistical significance. Thus, price support trading ahead of price drops is indeed the strongest for most predictable price drops.

Illiquid banks. In the main analysis, we exclude small and illiquid banks because they have a tiny free float and do not enter the portfolio of a typical mutual fund. In particular, instead of 12 identified publicly traded Spanish banks with at least one mutual fund family, we focus only on the 8 biggest and most liquid banks. The additional reason for excluding the smallest banks is the poor quality of analysts' data, which we need for our measure of Bad News. Indeed, the remaining four banks have either incomplete analyst coverage (Banco Atlantico and Banco Herrero) or they are covered by only a few analysts (Banco Zaragozano and Banco Guipuzcoano).

Now, we consider including in the analysis Banco Zaragozano and Banco Guipuzcoano, for which we have at least the full time series of the analysts' information, although Banco Guipuzcoano is sometimes covered only by a single analyst. As reported in Panel J, results based on all 10 banks are in line with the findings based on the 8 biggest and most liquid banks.

Price support in terms of portfolio weights. In the main analysis, we focus on the changes in holdings standardized by market capitalization. This is a natural way to control for price effects. We could, however, standardize holdings by the assets under management of the 
fund, and thereby test for price support in terms of increases in the weight of the parent bank stock in affiliated funds. A similar approach is also used in Massa and Rehman (2008) and Cohen and Schmidt (2009). Results reported in Panel K are aligned with the main results reported in the paper. The only difference relates to trading before anticipated price drops and after non-anticipated systematic bank price drops, where the estimated parameter on the interaction term of interest remains positive, but becomes insignificant. The results for trading after non-anticipated idiosyncratic price drops, however, remain strong and significant, in line with our hypothesis that price support interventions are largely driven by bank managers' incentives due to peer competition.

[Insert Table A.1: Robustness Checks] 